\title{
Constraints Perceived by the Farmers for Adoption of Alternate Wetting and Drying (AWD) Technology in Puri District of Odisha, India
}

\author{
Bibhu Prasad Dutta ${ }^{1^{*}}$, Amit Mishra ${ }^{2}$ and Aditya Prasad Kanungo ${ }^{1}$ \\ ${ }^{1}$ Department of Extension Education, College of Agriculture, OUAT, Bhubaneswar, India \\ ${ }^{2}$ Department of Soil Science and Agriculture Chemistry, Banda University of Agriculture and \\ Technology, Banda, Uttar Pradesh, India \\ *Corresponding author
}

\section{A B S T R A C T}

\begin{tabular}{l} 
K e y w o r d s \\
AWD, Pani Pipe, \\
$\begin{array}{l}\text { Constraints, water } \\
\text { saving technologies, } \\
\text { water scarcity }\end{array}$ \\
\hline Article Info \\
$\begin{array}{l}\text { Accepted: } \\
\text { 04 March } 2020 \\
\text { Available Online: } \\
\text { 10 April } 2020\end{array}$ \\
\hline
\end{tabular}

\section{Keywords}

AWD, Pani Pipe,

Constraints, water Saving technologies,

10 April 2020

\begin{abstract}
Alternate Wetting and Drying (AWD) is a simple and low cost water saving technology for helping farmers to cope up with the increasing water scarcity in irrigated environment. Irrigation is regulated by intermittent flooding in rice field with the help of Pani Pipe (perforated field tube). The study was carried out in Puri District of Odisha to ascertain the constraints perceived by the farmers that inhibit the adoption of AWD technology. All the selected farmers involved in adoption of AWD were interviewed as respondents. Different constraints social, technological, economical, organizational, ecological, biophysical etc. were prioritized on the basis of mean score and rank order analysis. Lack of awareness about new technology, lack of proper weed management knowledge, high cost for weed control in adoption of AWD, inadequate extension activities to develop confidence, presence of undulated land and lack of irrigation channels were the major constraints as per the farmers' perception. Suggestions were given for large scale adoption of the technology.
\end{abstract}

\section{Introduction}

Several water-saving technologies and practices have been developed to help farmers cope with water scarcity in irrigated environments. These include saturated soil culture, aerobic rice, and alternate wetting and drying (AWD) (Belder et al., 2005; Bouman et al., 2007). These water saving technologies are mostly aimed at reducing unproductive losses of water due to seepage, percolation, and evaporation, thereby increasing the productivity of total water inputs from rainfall and irrigation (Lampayan et al., 2014). AWD is a technology that has been widely tested and promoted in several countries in Asia, especially the Philippines, China, Vietnam, and Bangladesh (Lampayan et al., 2003).

Rice field is intermittently flooded with a dry spell in AWD which is monitored by use of a perforated field water tube (Pani Pipe). It is a simple and low cost technology in which rice plants can utilise the soil moisture up to 15 com root zone safely without any yield loss. 
In Odisha, most of the farmers are having marginal to small land holding and rice cultivation is only source of their income. Rice is the staple food of Odisha not only in terms of food habit but also a part of its social system. Mostly rice is grown in two seasons, such as rabi (dry season) and kharif (wet season) with prolonged or continuous irrigation. It is the prejudice and usual practice of farmers to maintain ponding water throughout the growth period of rice to make it a high water consuming crop. Irrigation water availability is shrinking day by day both from surface and ground water level. The dry season in Odisha remains almost fallow due to shortage of irrigation water in different parts of the state. Due to the above reasons, there is need to introduce water saving technologies like AWD in Odisha.

The irrigation sources are commonly managed by community instead of individual farmers in Odisha. The method of irrigation is mainly flooding which makes it difficult for implementation of AWD due to several social constraints. Despite of several advantages like saving of precise natural resource i.e. water and reduction of cost of cultivation several constraints are also involved that hinders the fast dissemination of AWD. That may be social, economic, technological and ecological etc. Consequently keeping those views in account, the study was formulated to ascertain the constraints perceived by the farmers that inhibit the adoption of technology.

\section{Materials and Methods}

The study was carried out during rabi-2015 in Puri District of Odisha. A total of 3blocks; Pipili, Nimapara, and Gop of Puri district were purposively selected in consultation with Cereal System Initiative for South Asia (CSISA) staff for the proposed study. These blocks were having rice growing areas in rabi season with assured irrigation source such as bore wells and lift Irrigation points. Three field days were conducted in each block for awareness of the technology among the farmers. Field days were arranged in collaboration with CSISA and Agricultural Dept., Govt. of Odisha. A total of 9 villages, 3 from each blocks and 144 farmers, 16 from each village were selected for the study. All the selected farmers involved in the experiment or adopting AWD were taken as a part of the study.

The study was under taken to ascertain various constraints associated with AWD in the particular study area. Constraints like social, technological, economical, organizational, ecological, biophysical etc. were taken into account for analyzing various constraints. The interview schedule was framed with three point's continuum over the framed statements under these variables. Information was collected from the respondent farmers through personal interview. Collected information was analyzed in terms of mean score by assigning weightage and rank order was prepared for the constraints on the basis of mean score.

\section{Results and Discussion}

It was clear from the table 1 that, lack of awareness about new technology was the most important constraint with mean score 3.6 followed by lack of confidence among farmer, low risk bearing ability having mean score $3.37,2.96$ respectively among the social constraints. As AWD is a new technology in Odisha, farmers were unaware of the technology. It was the first time they came across this technology. Due to that reason, maximum farmers had no awareness about the technology.

It is natural for a new technology or innovation to have less confidence among the 
farmers. Generally our farmers were marginal or small with low level of education having low risk bearing ability. They had to think a number of times before adopting a new technology from different perspectives.

Table.1 Constraints perceived by the farmer

\begin{tabular}{|c|c|c|c|}
\hline Sl. No. & Social Constraints & Mean Score & Rank \\
\hline 1. & Lack of family support & 1.94 & VIII \\
\hline 2. & Non co-operation and coordination among the farmers & 2.95 & IV \\
\hline 3. & Lack of awareness about new technology & 3.6 & I \\
\hline 4. & Lack of confidence among farmer & 3.37 & II \\
\hline 5. & Lack of initiative or poor leadership & 2.25 & VII \\
\hline 6. & Lack of consciousness of people & 2.79 & $\mathrm{~V}$ \\
\hline 7. & Low risk bearing ability & 2.96 & III \\
\hline 8. & Cattle menaces & 1.54 & $\mathrm{X}$ \\
\hline 9. & Chances of theft & 1.67 & IX \\
\hline \multirow[t]{2}{*}{10.} & Ownership of bore well & 2.72 & VI \\
\hline & Technological Constraints & & \\
\hline 1. & Lack of know how and do how of the technology & 3.03 & II \\
\hline 2. & Complex nature of technology & 1.63 & III \\
\hline 3. & Complex management practices in AWD & 1.59 & IV \\
\hline \multirow[t]{2}{*}{4.} & Lack of proper weed management knowledge & 3.16 & I \\
\hline & Economic constraints & & \\
\hline 1. & High cost for weed control & 2.55 & I \\
\hline 2. & Cost of Panipipe & 1.72 & II \\
\hline 3. & Increase in cost of plant protection chemicals & 1.51 & III \\
\hline \multirow[t]{2}{*}{4.} & Reduction in net income & 1.48 & IV \\
\hline & Organizational Constraints & & \\
\hline 1. & Lack of timely availability of expert & 2.45 & $\mathrm{~V}$ \\
\hline 2. & Weak extension system at village level & 3.31 & II \\
\hline 3. & Inadequate extension activities to develop confidence & 3.44 & I \\
\hline 4. & Lack of proper supervision & 2.64 & IV \\
\hline \multirow[t]{2}{*}{5.} & Lack of cooperation among staff and people & 2.7 & III \\
\hline & Ecological constraints & & \\
\hline 1. & Presence of undulated land & 2.88 & I \\
\hline 2. & Inadequate rainfall & 1.6 & IV \\
\hline 3. & Non availability of suitable land & 2.17 & II \\
\hline 4. & Non availability of irrigation facility & 2.12 & III \\
\hline \multirow[t]{2}{*}{5.} & Non availability of conducive climate & 1.58 & $\mathrm{~V}$ \\
\hline & Biophysical constraints & & \\
\hline 1. & Low tillering & 1.61 & IV \\
\hline 2. & More weed growth & 2.16 & III \\
\hline 3. & More insect pest infestation & 1.56 & $\mathrm{~V}$ \\
\hline 4. & Unavailability of irrigation at the time of need & 3.06 & II \\
\hline 5. & Lack of irrigation channels & 3.35 & I \\
\hline
\end{tabular}


Lack of proper weed management knowledge (Mean Score- 3.16) and Lack of know-how and do how of the technology (Mean Score3.03) were the major constraints with respect to the technological constraints. As the field is dried in AWD intermittently, there is chance of weed growth. But weed can be minimized or controlled by proper weed management practices most importantly by application of herbicides at right time and right dose. In Odisha particularly in the study area, most of the farmers were unaware of proper weed management practices. As a result, they had a fear of weed growth by drying the field. As AWD was a new technology and introduced for the first time, most of the farmers were unaware of the details of the technology. They were unaware of implementation of AWD and its proper benefits.

When economic constraints were concerned, the farmers had prioritized high cost for weed control in adoption of AWD. Weed is a real problem in case of AWD if not managed properly. It will lead to increase in cost of cultivation by increasing the cost for weeding. If weed is not minimized or controlled in the earlier stage, it is too expensive to control weeds.

It could be observed from the table 1, that farmers had prioritized organizational constraints as inadequate extension activities to develop confidence (3.44) followed by Weak extension system at village level (3.31), lack of cooperation among staff and people (2.7), lack of proper supervision (2.64) and lack of timely availability of expert (2.45) ranked $2^{\text {nd }}, 3^{\text {rd }}, 4^{\text {th }}$ and $5^{\text {th }}$ respectively in order of their importance.

So far as the ecological constraints concerned, presence of undulated land (2.88), nonavailability of suitable land (2.17), nonavailability of irrigation facility (2.12), inadequate rainfall (1.6), non-availability of conducive climate (1.58) was perceived by the farmers. In undulated land, upper level of land remains dry most of the time than the lower level on the same field. So it becomes a problem for complete and uniform drying in AWD.

It is quite clear from the table 1 that lack of irrigation channels (3.35), unavailability of irrigation at the time of need (3.06), and more weed growth (2.16) were the major constraints perceived by the respondents. Most of the fields are irrigated field to field. So it is difficult to follow AWD as fields can not be dried as per the need of an individual farmer. It is also related with social problems of non-cooperation and non-co-ordination among the farmers.

In conclusion from the analysis of above constraints, some suggestions can be generated for large scale dissemination and successful adoption of AWD:

Mass awareness campaign may be initiated on AWD technology. Integrated and collaborative efforts may be done by different public and private extension agencies to popularize AWD.

Confidence of farmers can be developed by conducting more demonstrations and on farm trials

Potential farm leaders in the village may be identified and motivated about the technology.

Community approach may be followed for AWD. People should be motivated to follow AWD in selected patches.

Farmers must be made aware with proper weed management knowledge before disseminating AWD. It will help them to reduce the weed growth and minimize the cost of weed control. 
Proper supervision and expert advice may be available in the initial stage to make it successful.

Farmers may be facilitated with suitable technology or machinery to level their fields properly.

Irrigation channels may be constructed for flow of irrigation water from one field to other field.

\section{References}

Belder P, Spiertz JHJ, Bouman BAM, Lu G, Tuong TP (2005) Nitrogen economy and water productivity of lowland rice under water-saving irrigation. Fields Crops Res 93:169-185

Bouman BAM, Lampayan RM, Tuong TP. 2007. Water management in irrigated rice. Coping with water scarcity. Manila, Philippines: International Rice Research Institute. p 53.
Lampayan RM, Samoy-Pascual KC, Sibayan EB, Ella VB, Jayag OP. 2014. Effects of Alternate Wetting and Drying (AWD) threshold level and plant seedling age on crop performance, water input, and water productivity of transplanted rice in Central Luzon, Philippines. Paddy Water Environment, DOI 10.1007/s10333014-0423-5

Lampayan RM, Bouman BAM, de Dios JL, Lactaoen AT, Espiritu AJ, Norte TM, Quilang EJP, Tabbal DF, Llorca LP, Soriano JB, Corpuz AA, Malasa RB, Vicmudo VR (2003) Adoption of water-saving technologies in rice production in the Philippines. Paper presented at the International Workshop on "Transitions in Agriculture for Enhancing Water Productivity,', Sep 2003, Tamil Nadu, India

\section{How to cite this article:}

Bibhu Prasad Dutta, Amit Mishra and Aditya Prasad Kanungo. 2020. Constraints Perceived by the Farmers for Adoption of Alternate Wetting and Drying (AWD) Technology in Puri District of Odisha, India. Int.J.Curr.Microbiol.App.Sci. 9(04): 181-185.

doi: https://doi.org/10.20546/ijcmas.2020.904.023 